\title{
Sistem Informasi Geografis Lahan Pertanian Rawan Kebakaran di Kota Singkawang
}

\author{
Fitri Imansyah ${ }^{\mathrm{a} 1}$ \\ ${ }^{a}$ Program Studi Teknik Elektro, Jurusan Teknik Elektro \\ Fakultas Teknik Universitas Tanjungpura \\ email : fitri.imansyah@ee.untan.ac.id
}

\begin{abstract}
Abstrak
Kebakaran hutan dan lahan yang hampir setiap tahun terjadi pada musim kemarau di Kota Singkawang, terutama disebabkan oleh faktor manusia. Kebakaran ini merupakan ancaman terhadap kelestarian hutan dan lahan, ekonomi, sosial, lingkungan dan bahkan politik. Dampak bencana ini tidak bisa dibendung oleh satu batas wilayah. Oleh karena masalah "tamu tahunan" ini harus dicegah dan ditanggulangi secara serius melalui berbagai aktivitas. Dalam rangka membantu untuk merencanakan pengeleloaan dibidang lahan pertanian khususnya lahan rawan kebakaran, dipandang perlu memanfaatkan sistem informasi geografis (SIG). Untuk membangun SIG diperlukan data utama yaitu data spasial (peta) dan data atribut (statistik). Kedua jenis data harus tersedia secara bersama-sama untuk memberikan informasi yang akurat. Masalah yang muncul bagaimana mentransformasikan kondisi real (real world) ke domain SIG, bagaimana manajemen datanya, dan bagaimana membangun aplikasi SIG yang bermanfaat sebagai salah satu unsur penunjang dalam pengambilan keputusan. Tujuan penelitian ini adalah terinventarisasi dan terdokumentasikannya data dan informasi pemetaan lahan pertanian rawan kebakaran baik secara numerik maupun spasial, sehingga dapat mendukung penetapan strategi penanggulangan kebakaran hutan dan lahan yang berdaya guna dan berhasil guna. Serta tersajikannya data dan informasi lahan pertanian rawan kebakaran dalam format yang accessible dan sesuai dengan standar baku perpetaan di Indonesia, sehingga memberi kemudahan dalam sinkronisasi program antar sektor.
\end{abstract}

Kata kunci: Rawan Kebakaran, Sistem Informasi Geografis, Data Spasial, Data Atribut, Manajemen Data.

\section{Geographical Information System for Fire Prone Agricultural Land in the city of Singkawang}

\begin{abstract}
Forest and land fires that occur almost every year during the dry season in Singkawang City are mainly caused by human factors. These fires are a threat to forest and land sustainability, economic, social, environmental, and even political. The impact of this disaster cannot be contained by one boundary. Therefore, the problem of "annual guests" must be prevented and addressed seriously through various activities. To help plan management in the field of agricultural land, especially fire-prone areas, it is deemed necessary to utilize a geographic information system (GIS). To build GIS, main data is needed, namely spatial data (maps) and attribute data (statistics). Both types of data must be available together to provide accurate information. The problems that arise are how to transform real conditions (real world) into the GIS domain, how to manage the data, and how to build a GIS application that is useful as a supporting element in decision making. The purpose of this research is to take inventory and document the data and information of mapping agricultural land prone to fire both numerically and spatially so that it can support the establishment of an efficient and effective forest and land fire prevention strategy. As well as the presentation of data and information on fire-prone agricultural land in a format that is accessible and by the standard mapping standards in Indonesia, to facilitate synchronization of programs between sectors.
\end{abstract}

Keywords: Fire Prone, Geographic Information System, Spatial Data, Attribute Data, Data Management.

\section{Pendahuluan}

Hutan dan lahan merupakan sumber daya alam yang sangat potensial untuk dimanfaatkan bagi pembangunan Nasional. Kendati demikian terhadap hutan dan lahan sering terjadi ancaman dan gangguan sehingga menghambat upaya-upaya pelestariannya. Salah satu bentuk ancaman dan gangguan tersebut adalah kebakaran hutan dan lahan [10]. Kebakaran hutan dan lahan mempunyai dampak buruk terhadap tumbuhan/tanaman, sosial ekonomi dan lingkungan hidup, sehingga kebakaran hutan dan lahannya bukan saja berakibat buruk terhadap 
hutan dan lahannya sendiri, tetapi lebih jauh akan mengakibatkan terganggunya proses pembangunan [3,4].

Sementara ini kebakaran hutan dan lahan masih dianggap sebagai suatu musibah/bencana alam seperti halnya gempa bumi dan angin topan, padahal kebakaran hutan dan lahan berbeda dengan kejadian-kejadian bencana alam tersebut. Kebakaran hutan dan lahan dapat dicegah/dikendalikan, karena kita telah mengetahui bahwa apabila musim kemarau, daerah rawan kebakaran tidak diadakan pencegahan sudah dapat dipastikan akan terjadi kebakaran hutan/lahan. Berdasarkan hal tersebut di atas, sudah saatnya pengendalian kebakaran hutan dan lahan ditangani secara terencana, menyeluruh, terpadu dan berkelanjutan $[2,12,15,18]$.

Sebagian besar kebakaran hutan dan lahan berasal dari kegiatan pembakaran pada sistem pengolahan lahan di pedesaan. Pembukaan kawasan hutan untuk membuka suatu areal baru bagi tanaman pangan sudah lama berlangsung. Setelah 2 atau 3 tahun ditanami tanaman pangan, lahan tersebut biasanya menjadi miskin hara dan ditinggalkan. Selanjutnya pembukaan kawasan hutan yang lainnya terjadi lagi untuk maksud yang sama. Demikian terus-menerus, bahkan meningkat sejalan dengan meningkatnya jumlah penduduk.

Kebakaran hutan dan lahan di Indonesia dan khususnya di Kalimantan Barat dalam lima belas tahun terakhir menunjukkan trend yang semakin meningkat frekuensinya dan dalam luasan yang makin meningkat, sehingga menimbulkan kerugian ekonomi, sosial, lingkungan dan bahkan politis yang semakin besar. Kebakaran hutan dan lahan umumnya disebabkan oleh faktor manusia, baik disengaja maupun tidak disengaja. Sangat sedikit kemungkinan akibat dari faktor alam (petir, gunung merapi dan lain-lain) $[5,9,14]$.

Berbagai upaya telah dilakukan untuk pencegahan dan penanggulangan kebakaran hutan, mulai dari penyuluhan, kampanye, pendidikan lingkungan, penyediaan peralatan, pelatihan dan pembentukan regu pemadam, dan bahkan pembentukan lembaga khusus pengendalian kebakaran hutan dan lahan. Penyebab kebakaran hutan dan lahan di Indonesia lebih $90 \%$ disebabkan oleh faktor manusia, baik disengaja maupun tidak disengaja (kelalaian), dan sangat sedikit yang disebabkan oleh faktor alam seperti akibat letusan gunung berapi, petir. Pada setiap daerah faktor kebakaran yang disebabkan oleh manusia sangat bervariasi, aktivitas manusia yang terkait dengan kebakaran hutan dan lahan antara lain: kegiatan konversi lahan $(35 \%)$, perladangan liar $(25 \%)$, pertanian $(17 \%)$, kecemburuan sosial (14\%), dan proyek transmigrasi $(8 \%)$ [7]. Ada empat penyebab kebakaran langsung yaitu: api digunakan dalam pembukaan lahan, api digunakan sebagai senjata dalam masalah konflik tanah, api menyebar secara tidak sengaja dan api yang berkaitan dengan ekstraksi sumberdaya alam $[6,13,16]$.

Maksud kajian ini adalah untuk menghasilkan rumusan kebijakan yang diharapkan dapat menjadi landasan penanganan kawasan pertanian yang rawan kebakaran di Kota Singkawang, untuk mencegah polusi udara sehingga terwujud Kota Singkawang sebagai kota yang nyaman dan layak untuk hidup (Livable) serta meningkatkan dan mengusahakan terciptanya suatu lingkungan yang sehat dan layak dengan perkembangan kota yang tertib dan teratur. Selain itu, maksud dari kajian ini sebagai masukan teknis bagi Pemerintah Kota Singkawang dalam mengarahkan para petani untuk mewujudkan lingkungan yang dikehendaki

Secara teknis tujuan kajian ini adalah sebagai berikut:

1) Terinventarisasi dan terdokumentasikannya data dan informasi pemetaan lahan pertanian rawan kebakaran baik secara numerik maupun spasial, sehingga dapat mendukung penetapan strategi penanggulangan kebakaran hutan dan lahan yang berdaya guna dan berhasil guna.

2) Tersajikannya data dan informasi lahan pertanian rawan kebakaran dalam format yang accessible dan sesuai dengan standar baku perpetaan di Indonesia, sehingga memberi kemudahan dalam sinkronisasi program antara sektor.

Sasaran lokasi kegiatan meliputi seluruh wilayah lahan pertanian yang sering terjadi kebakaran setiap tahunnya, yang terdapat di beberapa titik lahan pertanian dan hutan di Kota Singkawang. Dengan hasil yang diharapkan tersusunnya data spasial lahan pertanian rawan kebakaran sehingga dapat menghasilkan informasi yang komfrehensif mengenai kondisi dan distribusi lahan pertanian rawan kebakaran, sehingga dapat dimanfaatkan oleh instansi terkait dalam mengambil tindakan penaggulangan dini kebakaran lahan pertanian yang ada di Kota Singkawang.

Dampak yang diperkirakan dapat dirasakan dari pelaksanaan kegiatan ini adalah solusi dalam mengambil kebijakan untuk mencegah terjadinya kebakaran lahan pertanian dan hutan, serta arahan untuk malakukan tindakan dalam upaya mewujudkan Kota Singkawang bebas dari polusi udara.

Faktor-faktor terjadinya suatu kebakaran hutan dan lahan adalah karena adanya unsur panas, bahan bakar dan udara/oksigen. Ketiga unsur ini dapat digambarkan dalam bentuk segitiga api. Pada prinsipnya, pengendalian kebakaran hutan dan lahan adalah menghilangkan salah satu atau lebih dari unsur tersebut.

Kebakaran hutan dan lahan gambut selama musim kering dapat disebabkan atau dipicu oleh kejadian alamiah dan kegiatan atau kecerobohan manusia. Kejadian alamiah seperti terbakarnya ranting dan daun kering secara serta-merta (spontan) akibat panas yang ditimbulkan oleh batu dan benda lainnya yang dapat menyimpan dan menghantar panas, dan pelepasan gas metana $(\mathrm{CH} 4)$ telah diketahui dapat memicu terjadinya kebakaran. Meskipun demikian, pemicu utama terjadinya kebakaran adalah adanya kegiatan dan atau kecerobohan manusia, yang 90-95\% kejadian kebakaran dipicu oleh faktor ini [17,24].

Kebakaran ialah terbakarnya sesuatu yang menimbulkan bahaya atau mendatangkan bencana. Kebakaran dapat terjadi karena pembakaran yang tidak dikendalikan, karena proses spontan alami, atau karena kelalaian manusia. Sumber api alami ialah kilat yang menyambar pohon atau hangman, letusan gunung api 
yang menebarkan bongkahan bara api, dan gesekan antara ranting tumbuhan kering karena goyangan angin yang menimbulkan panas atau percikan api $[23,25,26]$.

Kebakaran hutan dan lahan yang hampir setiap tahun terjadi pada musim kemarau di Kalimantan Barat khususnya Kota Singkawang, terutama disebabkan oleh faktor manusia. Kebakaran ini merupakan ancaman terhadap kelestarian hutan dan lahan, ekonomi, sosial, lingkungan dan bahkan politik. Dampak bencana ini tidak bisa dibendung oleh satu batas wilayah. Oleh karena masalah "tamu tahunan" ini harus dicegah dan ditanggulangi secara serius melalui berbagai aktivitas.

Kebakaran hutan dan lahan tersebut harus dapat di "manage" dengan baik dalam rangka meminimalisir jumlah kejadian dan nilai dampak negatif (kerugian) yang ditimbulkannya melalui kegiatan pencegahan, operasional dan penginformasian dalam suatu sistem managemen terpadu yang dikelola oleh lembaga khusus pengendalian kebakaran sebagai leading agency.

Pencegahan kebakaran menjadi kegiatan utama, karena apabila kebakaran sudah melanda akan banyak menyita sumberdaya untuk mengatasinya dan kerugian besar akan menimpa. Upaya pencegahan kebakaran dilakukan antara lain dengan membangun kesadaran seluruh lapisan masyarakat agar peduli dalam upaya pencegahan kebakaran hutan dan lahan melalui pendidikan, penegakan hukum dan pengembangan teknis pencegahan serta pembuatan kebijakan yang mendukung upaya pencegahan kebakaran.

Institusi pemerintah, swasta, LSM dan organisasi massa atau kelompok masyarakat (maupun perorangan) sebenarnya dapat meningkatkan perannya aktivitas bersama didukung pendanaan yang memadai dalam membangun masyarakat yang peduli terhadap pencegahan kebakaran hutan dan lahan melalui pola hubungan kerjasama fungsional dan koordinasi dalam wadah jaringan kerja kegiatan pencegahan dan penanggulangan kebakaran hutan dan lahan ini.

Jaringan kerja pengendalian kebakaran merupakan salah satu alternatif untuk mengatasi berbagai kendala selama ini, dan merupakan hal strategis di dalam mewujudkan sistem pengelolaan kebakaran hutan dan lahan di Propinsi Kalimantan Barat dapat berjalan baik dan berkesinambungan dengan melalui beberapa aspek yang mutlak keberadaannya. Pengelolaan atas kebakaran hutan dan lahan gambut meliputi upaya pencegahan dan pengendalian. Kedua upaya itu harus dilakukan secara sistematis, serba-cakup (comprehensive), dan terpadu, dengan melibatkan semua pihak yang berkepentingan (stakeholder).

Tindakan pencegahan merupakan komponen terpenting dari seluruh sistem penanggulangan bencana termasuk kebakaran. Bila pencegahan dilaksanakan dengan baik, seluruh bencana kebakaran dapat diminimalkan atau bahkan dihindarkan. Pencegahan kebakaran diarahkan untuk meminimalkan atau menghilangkan sumber api di lapangan. Upaya ini pada dasarnya harus dimulai sejak awal proses pembangunan sebuah wilayah, yaitu sejak penetapan fungsi wilayah, perencanaan tata guna hutan/lahan, pemberian ijin bagi kegiatan, hingga pemantauan dan evaluasi.

Beberapa kegiatan yang dapat dilakukan untuk mencegah timbulnya api di antaranya:

1) Penatagunaan lahan sesuai dengan peruntukan dan fungsinya masing-masing, dengan mempertimbangkan kelayakannya secara ekologis dan ekonomis.

2) Pengembangan sistem budidaya pertanian dan perkebunan, serta sistem produksi kayu yang tidak rentan terhadap kebakaran, seperti pembukaan dan persiapan lahan tanpa bakar (zero burning-based land clearing), atau dengan pembakaran yang terkendali (controlled burning-based land clearing).

3) Pengembangan sistem kepemilikan lahan secara jelas dan tepat sasaran. Kegiatan ini dimaksudkan untuk menghindari pengelolaan lahan yang tidak tepat sesuai dengen peruntukan dan fungsinya.

4) Pencegahan perubahan ekologi secara besar-besaran diantaranya dengan membuat dan mengembangkan pedoman pemanfaatan hutan dan lahan gambut secara bijaksana (wise use of peatland), dan memulihkan hutan dan lahan gambut yang telah rusak.

5) Pengembangan program penyadaran masyarakat terutama yang terkait dengan tindakan pencegahan dan pengendalian kebakaran. Program ini diharapkan dapat mendorong dikembangkannya strategi pencegahan dan pengendalian kebakaran berbasis masyarakat (community-based fire management) [18].

6) Pengembangan sistem penegakan hukum. Hal ini mencakup penyelidikan terhadap penyebab kebakaran serta mengajukan pihak-pihak yang diduga menyebabkan kebakaran ke pengadilan.

7) 7. Pengembangan sistem informasi kebakaran yang berorientasi kepada penyelesaian masalah. Hal ini mencakup pengembangan sistem pemeringkatan bahaya kebakaran (Fire Danger Rating System) dengan memadukan data iklim (curah hujan dan kelembaban udara), data hidrologis (kedalaman muka ir tanah dan kadar lengas tanah), dan data bahan yang dapat memicu timbulnya api. Kegiatan ini akan memberikan gambaran secara kartografik terhadap kerawanan kebakaran. Gambarannya dapat berupa peta bahaya kebakaran yang berhubungan dengan kondisi mudahnya terjadi kebakaran, peta resiko kebakaran yang berkaitan dengan sebab musabab terjadinya kebakaran, dan peta sejarah kebakaran yang penting untuk evaluasi penanggulangan kebakaran [15,17].

\section{Dampak Kebakaran Lahan}

a. Dampak Terhadap Bio-Fisik

b. Dampak Terhadap Sosial Ekonomi

c. Dampak Terhadap Lingkungan

\section{Pengendalian Kebakaran}

Kegiatan pengendalian kebakaran meliputi kegiatan mitigasi, kesiagaan, dan pemadaman api. Kegiatan mitigasi bertujuan untuk mengurangi dampak kebakaran seperti pada kesehatan dan sektor transportasi yang disebabkan oleh asap [13,16].

Kesiagaan dalam pengendalian kebakaran bertujuan 
agar perangkat penanggulangan kebakaran dan dampaknya berada dalam keadaan siap digerakkan. Hal yang paling penting dalam tahap ini adalah membangun partisipasi masyarakat di kawasan rawan kebakaran, dan ketaatan para pengusaha terhadap ketentuan penanggulangan kebakaran.

\section{Peraturan Yang Mendukung}

Peraturan perundangan sangat penting dalam rangka pencegahan kebakaran hutan. Penegakan disiplin penggunaan api sangat perlu dilakukan, terutama terhadap mereka yang cenderung melanggar. Masyarakat perlu diberi informasi dan dididik mengenai aturan-aturan tersebut. Masih terdapat sejumlah kecil kelompok orang yang karena kepentingannya sendiri cenderung melanggar atau tidak peduli dengan aturan penggunaan api di tempattempat terlarang. Meskipun kelompok ini kecil, tapi seringkali mereka bisa menggagalkan upaya-upaya pencegah kebakaran. Oleh karenanya penegakan hukum tetap merupakan jalan satu-satunya untuk menjamin berhasilnya kegiatan pencegahan yang ditujukan terhadap orang-orang yang tidak peduli tersebut.

Pengenaan sanksi hukum kadang-kadang dipandang semata-mata sebagai penghukuman, padahal hal ini dapat menjadi sarana bagi tujuan yang baik. Jika hukum ditegakkan dan hukuman terhadap si pelanggar diumumkan, kemungkinan kejadian kebakaran dapat ditekan. Meski penegakan ketentuan hukum merupakan suatu bagian penting dari pencegahan kebakaran, hal ini sebaiknya dianggap sebagai suatu alat pendidikan yang harus digunakan secara arif dan bijaksana.

Peraturan perundangan harus direvisi, harus ada larangan untuk melakukan pembakaran yang menyebabkan kabut asap yang signifikan seperti pembakaran dilahan gambut, meskipun penggunaan api dalam situasi dan lokasi yang mungkin menimbulkan efek lokal yang tidak diinginkan dari asap misalnya terhadap asap dan transportasi, harus diatur. Berbagai dampak kebakaran dan kebakaran itu sendiri merupakan bagian dari masalah kebijakan dan bahwa dalam keadaan tertentu kebakaran mungkin merupakan cara pengelolaan lahan yang tepat. Pengakuan terhadap kenyataan ini memiliki implikasi perundang-undangan. Perundang-undangan Indonesia melarang semua pembakaran hutan dan lahan. Peraturan ini memfokuskan kebakaran sebagai masalah, yang harus dicegah dalam segala situasi [17,22,27,28,29].

\section{Keterkaitan Peta Dengan Penanggulangan Kebakaran Lahan}

Sistem Informasi Geografis yang memperpadukan setiap catatan dengan lokasinya pada peta, jadi juga pada lokasinya di bagian dunia nyata yang bersangkutan. Pada dasarnya sistem ini sepanjang keterangan (tekstual) datadata yang bersangkutan dicatat dalam file basis datanya, maka dapat menjawab pertanyaan pihak manajemen yang meliputi: Siapa, apa, bilamana, dimana dan berapa [19].

Dengan perancangan basis data yang serasi SIG dapat dipergunakan sebagai sarana manajemen. Selain itu, SIG dapat pula digunakan sebagai sarana bantu pengambilan keputusan yang mengandung implikasi keruangan, seperti dalam studi kemampuan lahan bagi pengembangan pertanian tertentu. Kemampuan tersebut berdasarkan terpenuhinya kriteria mengenai jenis tanah, kandungan hara, lereng, curah hujan dan sebagainya $[11,21]$.

Dari uraian di atas tersimpul kemampuan SIG sebagai:

a. Bank Data terpadu (data lokasi geografis dan data keterangan (tekstual) yang berkaitan).

b. Sistem Informasi

c. Sistem Analisa Keruangan

d. Sistem Administrasi/Manajemen Keruangan

e. Sarana bantu pengambilan keputusan (decission support system).

\section{Pendekatan Pengembangan}

Agar dalam waktu relatif singkat dapat terbentuk inti jaringan yang dapat diperlukan sebagai dasar bagi pengembangan selanjutnya, sistem akan dikembangkan sebagai berikut:

1) Sistem Berdasarkan Rujukan Persil

Sepanjang basis datanya mengandung data-data yang relevan, SIG sebagai sistem informasi dapat menjawab pertanyaan-pertanyaan mengenai siapa, apa, bilamana, dimana, dan berapa. Pertanyaan-pertanyaan tersebut adalah yang lazim dilontarkan oleh para eksekutif. Sebagai sistem administrasi, misalnya untuk Kantor Pendaftaran Tanah, SIG dapat dipergunakan untuk menampung data administratif mengenai persil, status tanah, tanggal perolehan dan harganya, nomor sertifikat dan sebagainya. Untuk Pajak Bumi dan Bangunan dapat pula disusun basis data yang mencakup data pengelolaan administrasi perpajakan.

2) Sistem Berdasarkan Rujukan Non-Persil (Geografis) Sektor pertanian setidaknya meliputi informasi mengenai jenis dan luas sawah, jenis dan luas pengairan. sumber air, jenis dan luas tanaman holtikultura, jenis dan luas perkebunan, serta potensi produksi masing-masing. Dengan pendekatan tersebut di atas, maka dapat dikembangkannya sekaligus dua jenis SIG, yakni SIG yang menggunakan persil/bidang tanah sebagai rujukan, dan SIG yang menggunakan unit administrasi atau area penyebaran fenomena sebagai rujukan (rujukan geografis)

\section{Konsep Implementasi}

Dalam hubungan itu pada tahap ini pembuatan peta dasar merupakan kegiatan yang bersifat strategis dan harus diprogramkan secara sistematis. Dalam rangka otonomi daerah, program ini makin penting untuk diselenggarakan secara sistematis dan berkelanjutan. Program diselenggarakan secara fotogrametris maupun terestris. Agar dapat menunjang secara optimal program pengembangan jaringan SIG, selayaknya untuk perdesaan dengan cara fotogrametris melalui pemotretan udara skala 1:10.000 dan secara terestris untuk perkotaan.

Untuk keperluan Kehutanan dan Pertanian yang memerlukan peta dasar dan peta tematik, perlu dipikirkan penggunaan sistem pengadaan data yang memadukan sekaligus pemetaan topografi dan pemetaan tematik, dengan sistem sensor yang mampu menghasilkan informasi dalam jenis dan detail yang diperlukan. Pada 
pelaksanaannya, selayaknya diadakan penjadwalan sedemikian rupa hingga secara relatif simultan diperoleh peta dasar dan peta kadaster [19].

Selain itu, dalam sistem Pemetaan Nasional, untuk keperluan perencanaan tata ruang daerah Kota akan diprogramkan penyusunan peta dasar rupabumi berskala 1:50.000 yang juga dapat dimanfaatkan untuk penyusunan SIG bersifat makro $[8,20]$.

Demikian juga untuk sektor kehutanan dan pertanian serta sektor lain yang menggunakan sistem rujukan geografis. Sementara itu peta dasar umum (berupa peta rupabumi), yang antara lain memuat batas-batas administratif, dapat digunakan sebagai peta rujukan bagi sistem informasi sosial politik dan kamtibmas, pendidikan, ketenagakerjaan, kesehatan dan sebagainya.

Untuk mencapai maksud dari pengembangan sistem ini perlu dilakukan analisis kebutuhan informasi Lokasi Kebakaran Lahan Kota Singkawang. Berdasarkan lima Informasi ini disusun suatu analisis kebutuhan informasi sebagaimana Tabel 1.

TABEL I

KEBUTUHAN INFORMASI KEBAKARAN LAHAN KOTA SINGKAWANG

\begin{tabular}{|l|l|}
\hline \multicolumn{1}{|c|}{ Jenis Informasi } & \multicolumn{1}{c|}{ Kebutuhan Informasi } \\
\hline $\begin{array}{l}\text { Informasi Lokasi } \\
\text { Kebakaran Lahan }\end{array}$ & $\begin{array}{l}\text { Legalitas Tanah } \\
\text { Status Lahan } \\
\end{array}$ \\
& Frekuensi Bencana Kebakaran \\
\hline
\end{tabular}

\section{METODOLOGI}

Dalam kegiatan ini, sistematika pelaksanaannya harus dilakukan melalui proses kegiatan dengan sequence (teratur) yang jelas mulai dari penseleksian lokasi Lahan Pertanian Rawan Kebakaran yang akan direncanakan dan program aksi rencana tindak sampai pada sistem informasi geografisnya.

Metode pendekatan studi yang akan digunakan dalam studi ini melalui beberapa tahapan sebagai berikut :

\section{A. Persiapan}

1. Koordinasi dengan Bappeda Kota Singkawang dan Dinas terkait.

2. Pengumpulan data sekunder

B. Observasi Lapangan

1. Inventarisasi potensi setiap daerah desa serta hambatan-hambatan yang berkaitan dengan pencegahan sektor Lahan.

2. Survey lapangan mengenai data geografis, luas area/lahan pertanian rawan kebakaran. Tahap awal adalah survey desa-desa pusat pertumbuhan (DPP) sebagai desa induk atau desa pusat lahan pertanian rawan kebakaran, pengumpulan data pendukung untuk setiap Lahan Pertanian Rawan Kebakaran dan mengkaji satuan-satuan wilayah pengembangan sebagaimana tercantum dalam rencana dan membaginya ke dalam kelompok menurut fungsi yang dikembangkan dan potensi dominan setiap desa.
C. Pembuatan Sistem Informasi Geografis

1. Disain sistem dengan merumuskan problem solving membuat sistem data flor menggunakan data flor diagram, hierarchy chart, entity relationship diagram, dan data dictionary.

2. Merepresentasikan masalah dengan merancang sistem kedalam program aplikasi dan Implementasi program ke dalam sistem nyata.

3. Melakukan testing dan evaluasi dari program aplikasi untuk menganalisa hasil yang dicapai.

Perangkat Lunak yang digunakan :

1. ArcMap: Untuk pengolahan data spatial.

2. Spatial Analyst dan 3D Analyst untuk menganalisa data spatial berdasarkan hasil pengukuran daerah yang menjadi objek kegiatan kedalam bentuk 2D dan 3D.

3. Data Terrain Model (DTM) Surface Area : Untuk menampilkan gambaran umum permukaan Lahan secara 3 dimensi berdasarkan ketinggian, sehingga dapat membentuk kontur dari Lahan yang akan dikembangkan.

4. Аvепие: Untuk mengoptimalkan unjuk kerja arcview GIS dengan menggunakan bahasa arcscript.

5. Arcview Extensions: merupakan tool yang dapat membantu proses pengolahan dan analisis data.

6. Arcv2Cad: merupakan aplikasi untuk mengkonversi dari file ArcView GIS ke file berformat $\mathrm{Cad}$ sehingga mempermudah proses pengolahan data spatial.

7. Mosaic Sattelite Imagery: merupakan potongan citra satelit resolusi spasial 1 meter.

8. Database System.

\section{Analisis Data}

1. Analisis potensi setiap daerah serta hambatanhambatan yang berkaitan dengan pencegahan pada sektor lahan dan penyusunan kebijakan.

2. Membuat strategi untuk mencegah terjadinya kebakaran lahan pertanian rawan kebakaran tersebut.

3. Penyusunan peta tematik daerah/kota, inventarisasi dan membuat database dari pengumpulan data tersebut.

\section{a. Pendekatan dan Metodologi Penyusunan Peta}

Pemetaanmerupakantahapan yang dilakukan seiring dan setelah tahapan analisis lahan pertanian rawan kebakaran dilakukan. Runtutan tahapan dalam penyusunan peta ini adalah :

1) Penyiapan peta dasar

2) Digitasi peta dasar

3) Pembentukkan simbol unsur-unsur peta

4) Inventaris data lahan pertanian rawan kebakaran

5) Penyajian peta tematik

b. Pendekatan dan Metodologi Penyusunan Sistem Informasi Lahan Pertanian Rawan Kebakaran

1) Prasyarat Sistem Informasi 
- Fungsional, yaitu sistem yang dibentuk bermanfaat dalam memberikan informasi perencanaan pencegahan kebakaran, yang berkaitan dengan kegiatan-kegiatan penanggulangan kebakaran hutan dan lahan pertanian di Kota Singkawang.

- Sustainable, artinya sistem yang dibentuk mampu untuk terus berkembang sesuai dengan kebutuhan aktivitas pembangunan ekonomi.

- Compatible, yaitu sistem yang dikembangkan harus memiliki kecocokan dengan sistem dan perangkat kerja yang sudah ada, serta memilki kecocokan secara umum dengan sistem-sistem informasi lain yang telah ada pada instansi.

- Mudah dan user friendly, sistem yang dikembangkan harus mudah dimengerti dan dioperasionalkan khususnya oleh calon pengguna.

- Handal, sistem informasi ini juga harus memuat kemampuan-kemampuan atau fungsi-fungsi informasi yang dibutuhkan.

- Layak dari segi biaya, artinya dalam pengembangannya harus disesuaikan dengan kemampuan daerah dalam penyediaan hardware dan software pendukung sistem, termasuk juga perawatan sistem.

2) Proses Pembentukan Sistem Informasi

- Identifikasi karakteristik sumber daya alam yang meliputi kondisi geografis, topografi, curah hujan, jenis tanah, sumber daya air dan sumber daya lainnya

- Identifikasi karakteristik sumber daya manusia yang meliputi jumlah penduduk, tingkat pendidikan penduduk dan mata pencaharian.

- Pemetaan lokasi Lahan Pertanian Rawan Kebakaran beserta informasinya

- Perancangan Model Sistem Informasi, termasuk sistem database keruangannya.

3) Perangkat Kerja

Perangkat kerja yang digunakan pada kegiatan penyusunan sistem informasi lahan pertanian rawan kebakaran Kota Singkawang dibedakan menjadi hardware, dan software komputer, disamping tenaga ahli dan operator pelaksana (brainware) yang menjadi konseptor dan pelaksana perancangan desain sistem.

4) Metodologi Umum Pengembangan Sistem Informasi Siklus pengembangan sistem dimulai denganpenaksiran kebutuhan-kebutuhan (needs assessment), dimana fungsi-fungsi sistem informasi beserta kebutuhan data diidentifikasi. Informasi ini didapat dengan beberapa cara antara lain dengan berdiskusi dengan pengguna sistem yang potensial. Baru kemudian, survei kebutuhan yang dilakukan berdasarkan informasi yang didapat dan perencanaan detil pengembangan sistem informasi diformulasikan.

5) Penaksiran Kebutuhan

Penaksiran kebutuhan dirancang untuk menghasilkan dua jenis informasi penting jumlah fungsi-fungsi sistem informasi yang diperlukan dan daftar master data. Kedua jenis informasi ini diekstrak dari sekumpulan deskripsi aplikasi sistem informasi, daftar data penting, dan deskripsi proses-proses manajemen. Selain itu, akan digunakan formulir standard untuk mendokumentasikan hasil-hasil interview dengan pengguna. Informasi yang didapat dari aktivitas penaksiran kebutuhan ini secara langsung mempengaruhi aktivitas perancangan sistem informasi secara konseptual.

6) Perancangan Konseptual Aplikasi

Perancangan konseptual Aplikasi Sistem Informasi pada mulanya merupakan suatu perancangan basisdata. Aktivitas ini mencakup pemodelan formal (persiapan model data) basisdata Sistem Informasinya dan tingkatan awal dari aktivitas perencanaan basisdata. Perencanaan basisdata merupakan aktivitas yang paling penting di dalam pengembangan Sistem Informasi. Aktivitas ini dimulai dari pengenalan kebutuhan mengenai data-data di dalam penaksiran kebutuhan, updating dan pemeliharaan data dan akhirnya penyimpanan data sesuai dengan jadwalnya [1]. Perancangan konseptual ini meliputi:

- Perancangan Sistem dan Prosedur: Berdasarkan hasil survey, analisis sistem dan prosedur, dilakukan pembuatan rancangan dan menyusun konsep sistem dan prosedur.

- Perancangan Konsep: Pada tahap ini akan disusun suatu konsep sistem yang terintegrasi dan terdiri dari klasifikasi data, model-model aplikasi.

\section{HASIL DAN PEMBAHASAN}

GIS (Geographic Information System) sampai saat ini yang mampu melakukan visualisasi secara efektif mengenai kondisi geografis yang akurat, kejadian bencana kebakaran, ataupun perkiraan ancaman kebakaran yang akan terjadi. Informasi spasial tersebut akan sangat membantu fire manager di dalam melakukan identifikasi dan perencanaan, pencegahan, persiapan, respon serta restorasi.

Peta rawan kebakaran merupakan model spasial yang digunakan untuk mempresentasikan kondisi di lapangan terkait dengan resiko terjadinya kebakaran hutan dan lahan. Model ini dibuat menggunakan aplikasi GIS untuk memudahkan proses overlay antar faktor-faktor penyebab kebakaran. Karenanya, memahami faktor-faktor penyebab dan perilaku kebakaran hal yang sangat utama di dalam melakukan pemodelan ini.

Penilaian (Scoring) dilakukan dengan menggunakan hasil analisa dari penyebaran hotspot selama musim kemarau panjang, yang lebih menarik dan relevan bagi fire manager untuk bahan pertimbangan musim kebakaran selanjutnya. Hasil analisa frekuensi hotspot dari berbagai faktor tersebut selanjutnya di klasifikasi ke dalam beberapa kelas nilai (misalnya 1-5). Sedangkan pembobotan (weighting) dilakukan dengan menggunakan penilaian berdasarkan pengetahuan serta kondisi yang terjadi di lapangan (expert judgement). Faktor dengan pengaruh lebih besar memdapatkan pembobotan yang lebih besar dibandingkan factor lainnya. Dalam hal ini pengaruh penutupan lahan dianggap lebih besar disbanding faktor lainnya, mengigat selain terkait dengan data vegetasi, penutupan lahan juga terkait dengan penggunaan lahan, seperti pertanian, perkebunan, Hutan Tanaman Industri, dan lain-lain. 
Bahan penelitian yang digunakan adalah berupa data sample baik tabular maupun spasial dari daerah pertanian yang ada di Kota Singkawang yang di dapat dari Dinas Pertanian Kota Singkawang dan Badan Penanggulangan Bencana Daerah Kota Singkawang. Selain itu juga digunakan data tematik yang dapat mendukung analisis daerah pertanian rawan kebakaran kota singkawang berupa data jenis tanah, data daerah rawan kebakaran kota singkawang dan data tutupan lahan yang dihubungkan dengan data perubahan sosial, budaya dan perekonomian masyarakat yang ada di Kota Singkawang serta sebaran titik hotspot.

Adapun indikator yang mempengaruhi kebakaran lahan pertanian adalah sebagai berikut:

\section{A. Data Tutupan Lahan}

Data tutupan lahan adalah data tematik yang menggambarkan kondisi existing permukaan bumi beserta apa yang ada di wilayah permukaan bumi tersebut. Kota Singkawang adalah salah satu kota terkecil yang ada di Kalimantan Barat dimana sebagian besar wilayahnya tertutup oleh lahan pertanian yang kemudian disusul oleh tutupan hutan dan semak belukar. Hal ini dapat dilihat pada peta tutupan lahan Kota Singkawang dibawah ini.

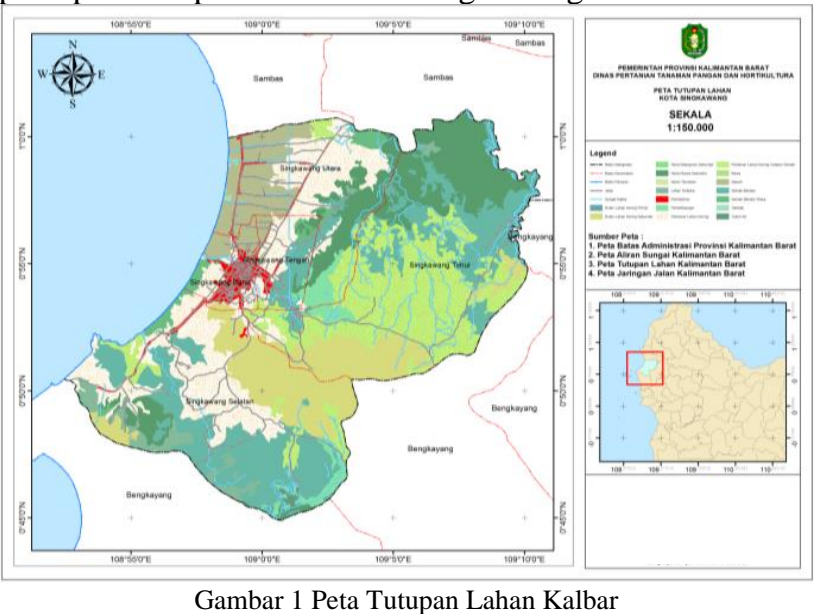

Jika dilihat dari gambar diatas memang Kota Singkawang berpotensi terjadinya kebakaran lahan dan hutan dikarenakan daearah Kota Singkawang sebagian besar tutupan lahannya adalah berupa Pertanian lahan kering dan bersemak, hutan dan semak belukar.

\section{B. Data Jenis Tanah}

Data jenis tanah adalah data tematik yang menggambarkan kondisi existing jenis tanah yang terdapat pada permukaan bumi. Sebagian besar Daerah Kota Singkawang berjenis tanah PMK hal ini dapat dilihat pada gambar 2 berikut.

Jika dilihat dari gambar 2 memang Kota Singkawang berpotensi terjadinya kebakaran lahan dan hutan dikarenakan daearah Kota Singkawang sebagian besar jenis tanahnya adalah tanah gambut. Hal ini mengakibatkan Kota Singkawang sangat berpotensi terjadinya kebakaran hutan dan lahan.

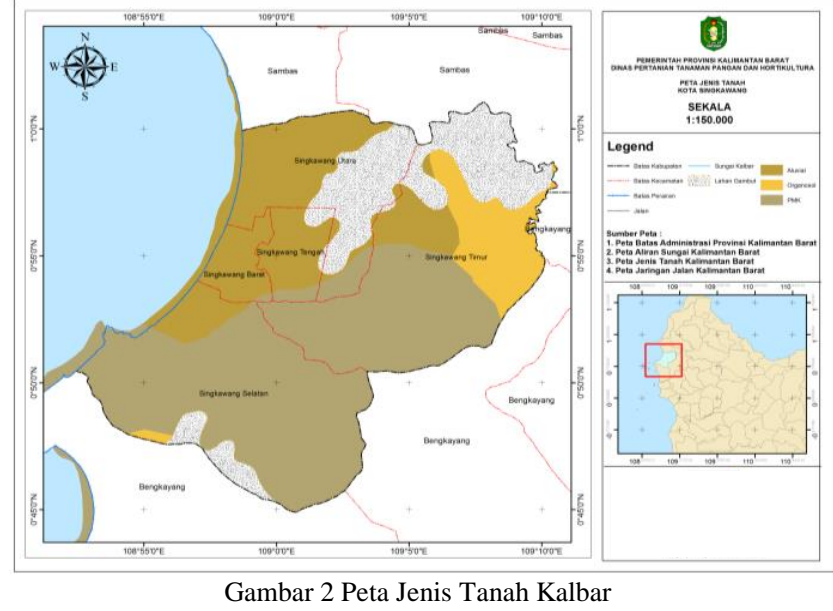

\section{Data Sebaran Pemukiman Penduduk}

Data sebaran Pemukiman Penduduk adalah data tematik yang menggambarkan penyebaran pemukiman penduduk diatas permukaan bumi. Penyebaran penduduk di daerah Kota Singkawang tidak begitu merata untuk tiap Kecamatannya. Hal ini dapat dilihat pada gambar berikut.

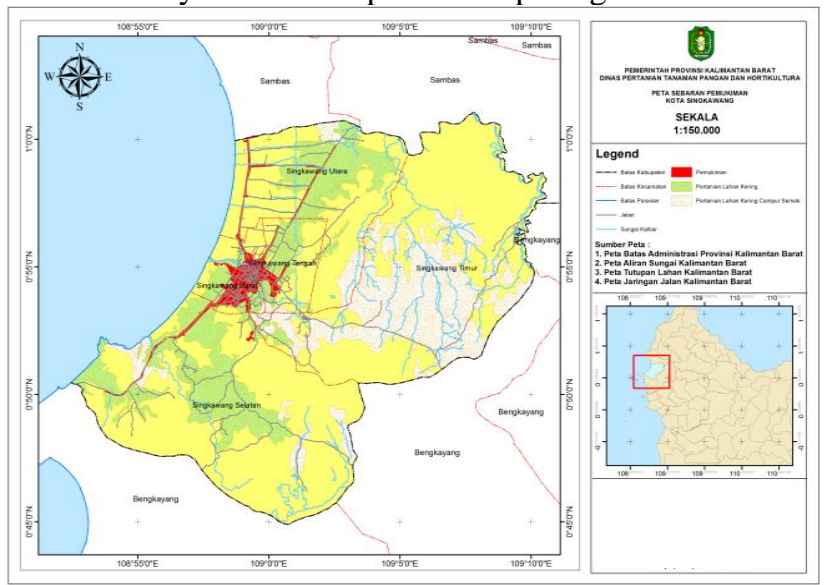

Gambar 3 Peta Sebaran Penduduk

Dari gambar diatas dapat dilihat bahwa perbandingan antara pemukiman dan lahan non pemukiman sangatlah berbeda jauh. Hal ini bisa menjadi salah satu penyebab terjadinya kebakaran lahan khususnya lahan pertanian yang disebabkan oleh manusia. Begitu banyaknya lahan yang tidak termanfaatkan tersebut memicu masyarakat untuk membuka lahan dengan berbagai cara salah satunya dengan membakar.

\section{Data Sebaran Titik Hotspot}

Titik hotspot adalah titik panas permukaan bumi yang terdeteksi oleh satelit. Terdeteksinya titik hotspot tidak hanya disebabkan oleh kebakaran hutan saja tetapi juga bisa disebabkan oleh pantulan atap seng rumah maupun kaca gedung.

Tetapi titik hotspot juga bisa digunakan sebagai salah satu indikator atau bahan pertimbangan untuk menganalisis daerah pertanian rawan kebakaran apabila titik hotspot tersebut berada di lahan pertanian atau di semak belukar dan lahan kosong lainnya. Sebaran titik hotspot Kota Singkawang dapat dilihat pada gambar berikut. 


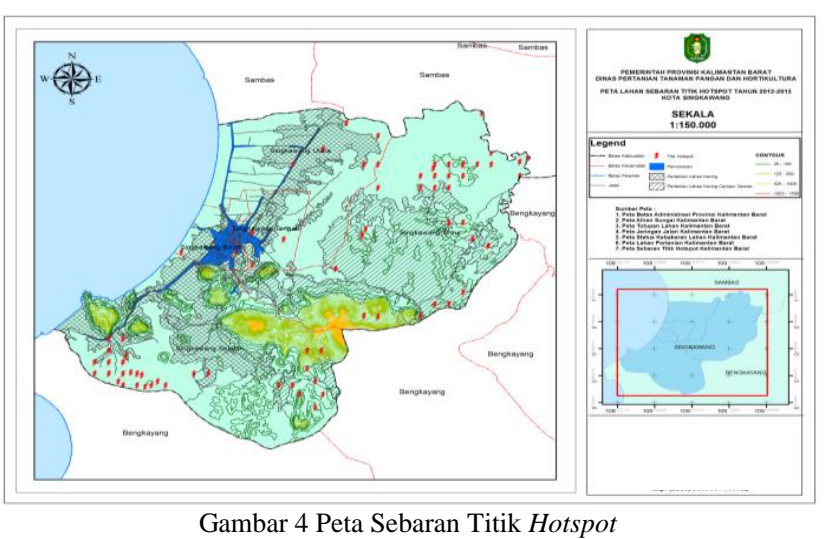

Pemetaan lahan pertanian rawan kebakaran berbeda dengan pemetaan yang lain dimana hanya menggunakan satu variabel data saja. Untuk memetakan lahan pertanian rawan kebakaran harus dengan metode overlay layer yang kemudian dianalisis. Dari data dan variabel-variabel tersebut yang dihubungkan dengan GIS akan lebih tampak kondisi eksisting suatu wilayah pertanian rawan kebakaran. Secara umum, lahan pertanian yang ada di Kota Singkawang setelah di overlay-kan dengan data tematik lain dapat dilihat pada gambar berikut.

1. Sebaran Lahan Pertanian Rawan Kebakaran Terhadap Tutupan Lahan

Jika di lihat dari tutupan lahan, sebaran lahan pertanian rawan kebakaran memang berada di daerah yang paling dekat dengan pemukiman penduduk. Hal ini dapat dilihat pada gambar 5 .

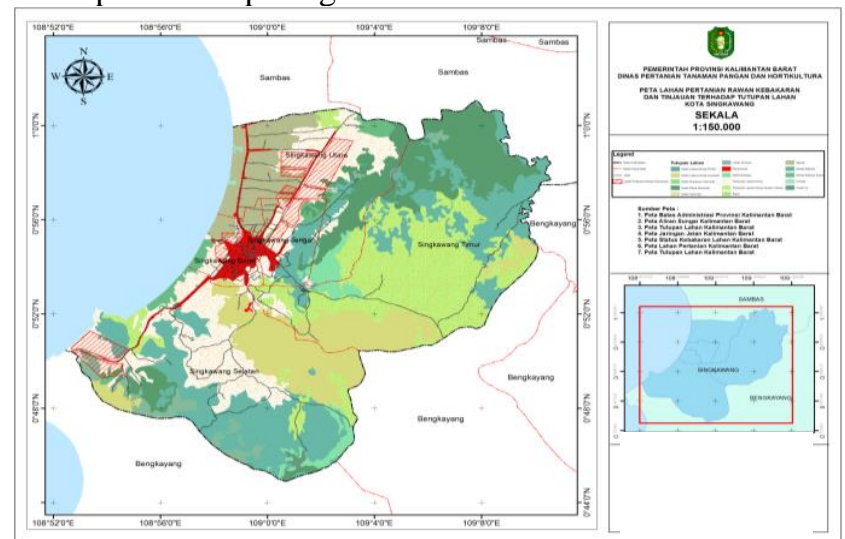

Gambar 5 Peta Sebaran Lahan Pertanian Rawan Kebakaran Terhadap Tutupan Lahan Kota Singkawang

Manusia merupakan salah satu faktor utama penyebab terjadinya kebakaran lahan. Minimnya kesadaran dan pengetahuan akan bagaimana pengolahan lahan yang baik dan benar pada kawasan pertanian lahan pertanian kering campuran dan semak belukar yang tersebar di Kota Singkawang merupakan dasar terjadinya pembakaran lahan oleh manusia. Demi untuk menghemat biaya dan mempercepat membuka suatu lahan, masyarakat yang tinggal di sekitar lahan pertanian kering campuran dan semak belukar rela melakukan pembakaran lahan yang berakibat buruk bagi masyarakat luas.

2. Sebaran Lahan Pertanian Rawan Kebakaran Terhadap Status Lahan Rawan Kebakaran
Jika ditinjau dari sebaran status lahan rawan kebakaran Kalimantan Barat, memang, kawasan pertanian yang berada di dekat pemukiman cederung lebih ekstrim dibanding dengan yang sedikit jauh dengan pemukiman. Hal ini dapat dilihat pada gambar 6 .

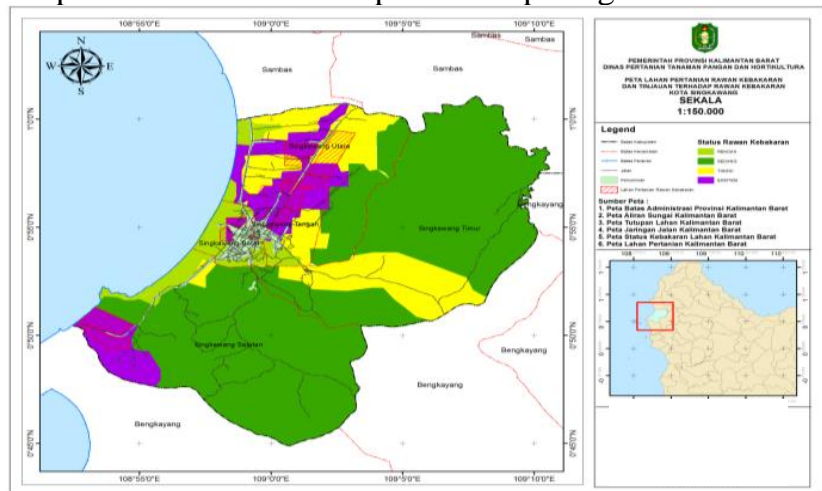

Gambar 6 Peta Sebaran Lahan Pertanian Rawan Kebakaran Terhadap Status Kawasan Rawan Kebakaran

Dari gambar 6, terlihat jelas bahwa Kota Singkawang bagian pesisir lebih cenderung mudah terjadinya kebakaran lahan di banding dengan daerah pedalaman. Mengapa demikian, kembali lagi pada poin pertama, bahwa penduduk Kota Singkawang lebih padat pada bagian pesisirnya di banding pedalamannya.

3. Sebaran Lahan Pertanian Rawan Kebakaran Terhadap Ketinggian

Ketinggian permukaan suatu kawasan juga berpengaruh terhadap terjadinya kebakaran. Hal ini di karenakan semakin tinggi lahan tersebut berada cenderung sulit untuk terjadinya kabakaran dan sebaliknya. Ketinggian juga mempengaruhi struktur tanah yang berdampak langsung terhadap jenis tanaman yang ada di atasnya.

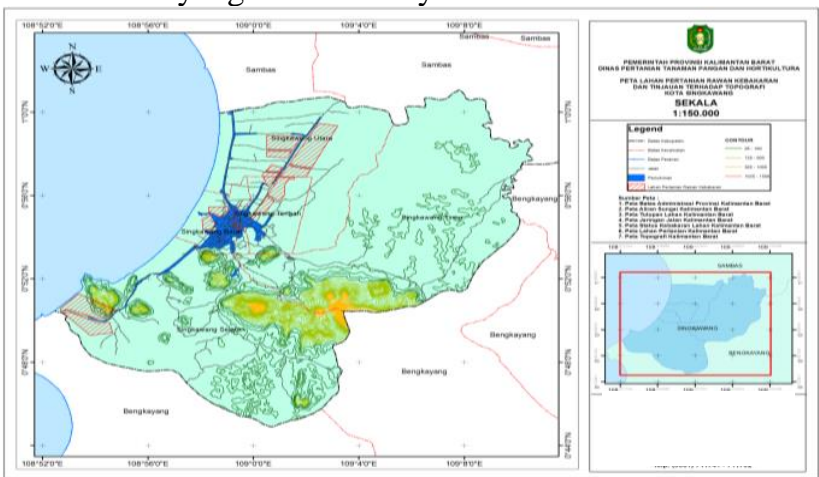

Gambar 7 Peta Sebaran Lahan Pertanian Rawan Kebakaran Terhadap Ketinggian Suatu Lahan

Dari gambar diatas dapat dilihat bahwa lahan pertanian yang rawan terjadinya kebakaran berada di rata-rata ketinggian sekitar $0-100 \mathrm{~m}$ diatas permukaan permukaan laut.

4. Sebaran Lahan Pertanian Rawan Kebakaran Terhadap Jenis Tanah

Kota Singkawang memiliki empat jenis tanah yang terdiri dari Aluvial, Organosol, PMK (podsolid merah kuning), gambut. Jenis tanah akan berpengaruh terhadap tumbuhan yang ada di atasnya. Kota Singkawang di dominasi oleh jenis tanah PMK 
(podsolid merah kuning) yang tersebar merata di Kecamatan Singkawang Selatan. Untuk lahan pertaniannya, banyak terdapat pada daerah yang berjenis tanah aluvial.

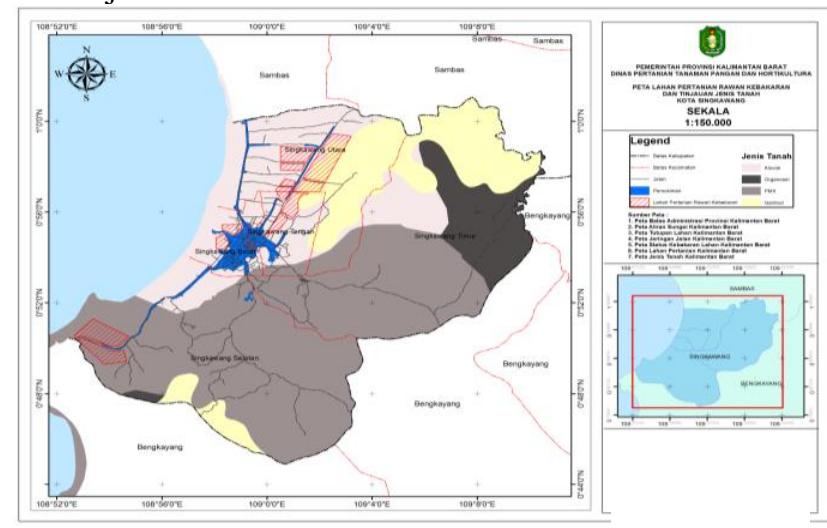

Gambar 8 Peta Sebaran Lahan Pertanian Rawan Kebakaran Terhadap Jenis Tanah

Gambar 8 menunjukkan bahwa sebagian besar lahan pertanian rawan kebakaran yang ada di Kota Singkawang berada di Singkawang Barat, Tengah dan Utara. Hal ini disebabkan karena daerah tersebut memiliki struktur tanah berjenis aluvial dan gambut.

Tanah aluvial adalah tanah campuran yang terdiri dari pasir putih dan hitam yang diatasnya terdapat lapisan gambut tipis atau pelapukan dari jenis pohon besar maupun kecil yang sudah lama. Hal mengakibatkan lahan yang ada di atas tanah aluvial tersebut cenderung mudah untuk terbakar baik kebakaran yang tanpa sengaja maupun yang disengaja.

Lahan pertanian rawan kebakaran di Kota Singkawang tersebar di empat kecamatan yaitu Kecamatan Singkawang Barat, Tengah, Selatan dan Utara. Dari keempat kecamatan tersebut memilki jumlah lokasi dan luasan lahan pertanian rawan kebakaran yang berbeda. Singkawang Utara merupakan kecamatan yang memiliki lahan pertanian rawan kebakaran yang paling banyak. Hal ini dikarenakan faktor tanah, ketinggian, tumbuhan yang ada di atasnya dan pemukiman masyarakat yang dekat dengan lahan pertanian. Peta sebaran lahan pertanian rawan kebakaran dapat dilihat pada gambar berikut.

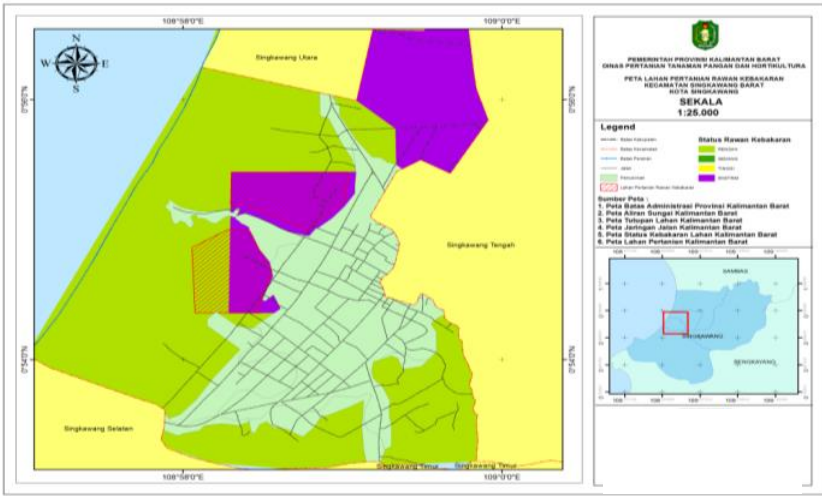

Gambar 9 Peta Lahan Pertanian Rawan Kebakaran Kecamatan Singkawang Barat

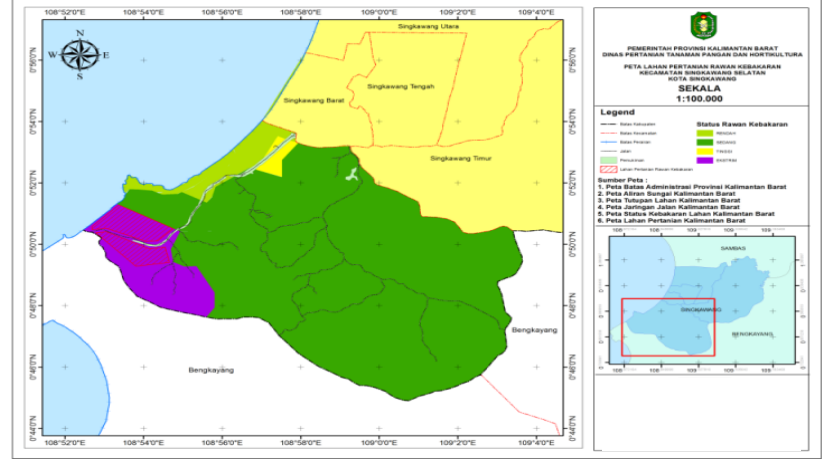

Gambar 10 Peta Lahan Pertanian Rawan Kebakaran Kecamatan Singkawang Selatan

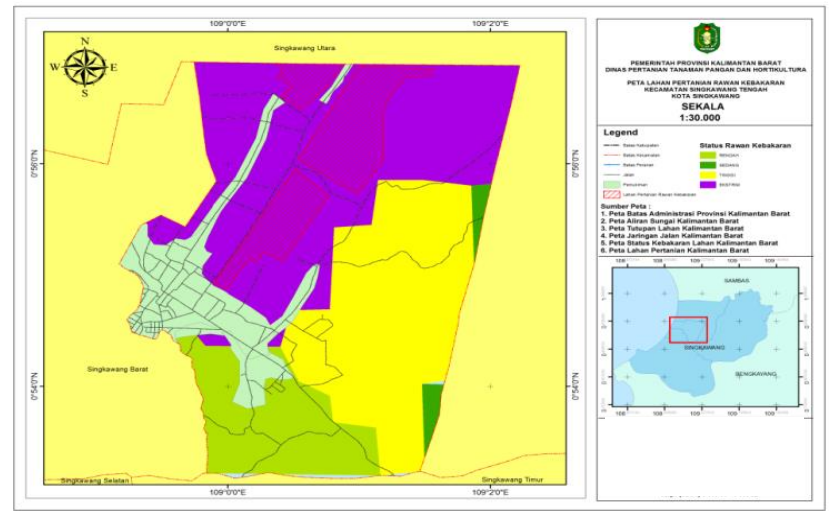

Gambar 11 Peta Lahan Pertanian Rawan Kebakaran Kecamatan Singkawang Tengah

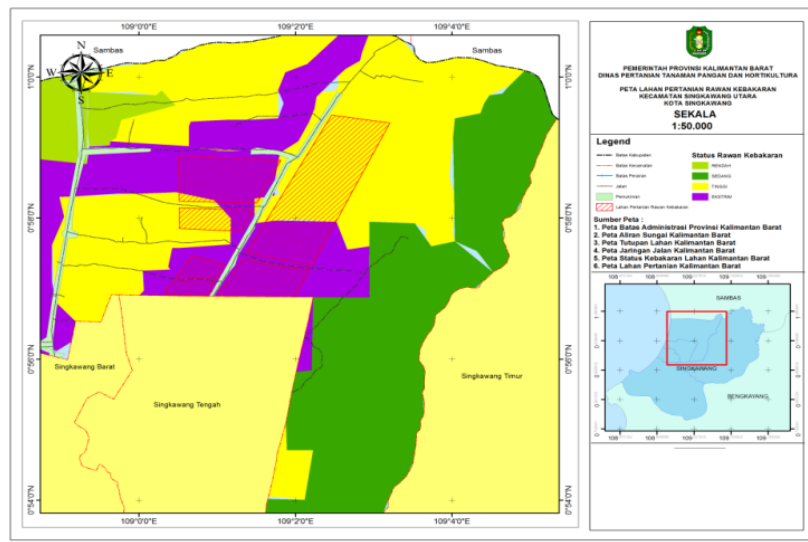

Gambar 12 Peta Lahan Pertanian Rawan Kebakaran Kecamatan Singkawang Tengah

\section{KESIMPULAN}

Setelah dilakukan penelitian, maka dapat disimpulkan bahwa :

1) Kebakaran hutan dan lahan yang hampir setiap tahun terjadi pada musim kemarau di Kota Singkawang, terutama disebabkan oleh faktor manusia.

2) Penyebab kebakaran lahan adalah sebagai berikut:

- Pembukaan lahan dengan cara pembakaran, masih dilakukan karena lebih mudah, murah dan cepat

- Fenomena alam berupa musim kemarau panjang (Sambaran petir pada hutan yang kering karena musim kemarau yang panjang). 
- Terdapat lahan gambut yang cukup rentan terhadap api.

- Kepedulian masyarakat masih rendah

- Aksesibilitas kelokasi kebakaran sulit dijangkau

- Sumber air tidak tersedia

- Sarana dan prasarana Pemadam Kebakaran Hutan terbatas

- Belum semua instansi berperan aktif secara optimal

- Kecerobohan manusia antara lain membuang puntung rokok secara sembarangan dan lupa mematikan api di perkemahan.

- Tindakan yang disengaja seperti untuk membersihkan lahan pertanian atau membuka lahan pertanian baru dan tindakan vandalisme.

- Kebakaran di bawah tanah/ground fire pada daerah tanah gambut yang dapat menyulut kebakaran di atas tanah pada saat musim kemarau.

3) Langkah-langkah yang telah dan akan dilakukan sebagai bentuk upaya pencegahan kebakaran, diantaranya:

- Deteksi Dini dan Peringatan Dini

- Pelatihan Keterampilan Penanggulangan Karhutla bagi kelompok masyarakat $\pm 30-60$ Orang/tahun dan peningkatan SDM bagi petugas Pemprov, Pemkab/Pemkot

- Peningkatan koordinasi dan kerjasama antara Pemprov dengan Pemkab/Pemkot

- Membuat Peta Kerawanan KARHUTLA

- Patroli/Pengawasan Daerah Rawan KARHUTLA

- Menginstruksikan kepada perusahaan perkebunan dan Kehutanan untuk tidak melakukan pembakaran serta membina masyarakat yang berada diwilayah kerjanya.

4) Keterjangkauan masyarakat lokal terhadap lahan sudah semakin kecil, sehingga sebagian besar masyarakat mengoptimalkan pemanfaatan lahan yang ada. Semakin kecilnya keterjangkauan tersebut, disebabkan: (a) luasan lahan non gambut hingga bergambut $<1,5$ meter berkisar $10-15 \%$ dari luas wilayah desa; (b) status kepemilikan lahan sudah semakin kukuh; (c) nilai lahan sudah tergolong tinggi; (d) batas-batas wilayah desa yang semakin jelas; dan (e) penegakan sanksi bagi penembangan hutan dan pembakaran lahan.

5) Pemahaman masyarakat lokal terhadap kebakaran di lahan gambut masih relatif lemah. Pemahaman masyarakat masih berkisar fenomena kebakaran di permukaan (surface fire), sementara fenomena kebakaran bawah (ground fire) dan kebakaran tajuk (crown fire) jauh dari pemahaman mereka.

6) Pemahaman masyarakat terhadap dampak kebakaran lahan gambut juga relatif lemah. Bagi masyarakat, dampak kebakaran gambut hanya berkisar masalah asap dan tanah yang mengeras. Sedangkan dampaknya terhadap kerusakan ekosistem dan biodiversitas serta perubahan lingkungan global belumbanyakdipahami.
7) Kebakaran yang terjadi di lahan gambut sebagian besar terjadi di lahan yang tidak dikelola oleh masyarakat. Kebakaran sebagian besar berawal dari kawasan hutan dan semak belukar, namun pelaku ataupun penyebab kebakaran belum diketahui dengan pasti. Kebakaran yang berasal dari lahan masyarakat masih sangat jarang terjadi, jika pun ada maka kebakaran yang ditimbulkan tidak begitu luas.

8) Keterlibatan masyarakat dalam melakukan pengendalian kebakaran lahan dan hutan semakin berkembang. Kebiasaan "handep hapakat" (gotong royong) masih melekat kuat dalam kehidupan bermasyarakat tetap digalakkan.

\section{DAFTAR PUSTAKA}

[1] Abdul Kadir, (2010), Mudah Mempelajari Database My SQL, Andi Offset, Yogyakarta.

[2] Adinugroho WC, Suryadiputra INN, SaharjoBH, SiboroL. (2005) Panduan Pengendalian Kebakaran Hutan dan Lahan Gambut. Proyek Climate Change, Forestsand Peat lands in Indonesia. Bogor: Wetlands International-Indonesia Programme dan Wildlife Habitat Canada (WHC).

[3] Andria AY. (2009). Keterkaitan Faktor Biofisik dan Penguasaan Lahan Hutan dengan Kerawanan Kebakaran Hutan dalam Perspektif Penataan Ruang (Studi Kasus pada Wilayah Hutan Tanaman Industri di Jambi) [tesis]. Bogor: Institut Pertanian Bogor.

[4] Anonim, (1998). Kebakaran Hutan dan Lahan di Indonesia, Dampak, Faktor dan Evaluasi. Kantor Menteri Negara Lingkungan Hidup - UNDP. Jakarta.

[5] Anonim, (1998). Kebakaran Hutan dan Lahan di Indonesia, Rencana Tindak Penanggulangan Bencana. Kantor Menteri Negara Lingkungan Hidup - UNDP. Jakarta.

[6] Anonim, (2003). Rencana Strategis Pengendalian Kebakaran Hutan dan Lahan Kalimantan Timur Tahun 2004 - 2008. UPTD Pengendalian Kebakaran Hutan dan Lahan, Dinas Kehutanan Propinsi Kalimantan Timur. Samarinda.

[7] Anonim, (2003). Pengelolaan Kebakaran Hutan dan Lahan Terpadu di Kalimantan Timur. Makalah pada Pelatihan Kebakaran Hutan dan Lahan di Jayapura, Propinsi Papua). Tidak dipublikasikan.

[8 ]Ajriansyah Putra, Ambar Tri Ratnaningsih, Muhammad Ikhwan, (2018), Pemetaan Daerah Rawan Kebakaran Hutan dan Lahan Dengan Menggunakan Sistem Informasi Geografis (Studi Kasus: Kecamatan Bukit Batu, Kab. Bengkalis), Wahana Foresta, Jurnal Kehutanan, Vol 13, Nomor 1 Januari 2018.

[9] Arianti,Iin. (2006). Pemodelan Tingkat dan Zona Kerawanan Kebakaran Hutan dan Lahan Menggunakan SIG di SubDas Kapuas Tengah Provinsi Kalimantan Barat. Bogor: Institut Pertanian Bogor.

[10] Chokkalingam, U. (2004). Fire Causes in East Kalimantan. Centre for International Forestry Research (Bahan Presentasi pada Konferensi Pengelolaan Kebakaran Hutan dan Lahan di Samarinda Mei 2004

[11] Dydik Setyawan, Yuli Priyana, Agus Anggoro Sigit, (2014), Pemodelan Spasial Arah Penyebaran Kebakaran Hutan Dengan Menggunakan Penginderaan Jauh Dan Sistem Informasi Geografis Di Taman Nasional Baluran Kabupaten Situbondo Provinsi JawaTimur, Fakultas Geografi Universitas Muhammadiyah Surakarta.

[12] FWI/GFW, (2001) Potret Keadaan Hutan Indonesia. Bogor. Indonesia : Forest Watch Indonesia. Washington D.C. : Global Forest Watch.

[13] Gandasasmita K. (2010) Pengembangan Geo indikator untuk Pengelolaan Resiko Kebakaran Hutan dan Lahan. Workshop: Pengembangan Indikator Geoindikator Untuk Pengelolaan Resiko Bencana, Lingkungan dan Penataan Ruang di Indonesia, Bogor 01 Des 2010. 
[14] Haase, N. (2002). The Economic Losses to East Kalimantan From The 1997/1998 Forest and Land Fires. IFFM Document. No. 29. Samarinda.

[15] Hoffman A. A., dkk. (1999). Fire Damage in East Kalimantan in 1997/1998 Related to The Land Use Vegetation Classes : Satellite Radar Inventory Result and Proposals for Future Actions. IFFM and SFMP Docoment No. 20. Samarinda.

[16] Kadri, W. dkk. (1982). Manual Kehutanan. Departemen Kehutanan Republik Indonesia. Jakarta.

[17] MaingiJK. (2005). Mapping FireScars in a Mixed-Oak Forest in Eastern Kentucky, USA,Using Landsat ETM+Data. Geocarto International 20(3):51-63.

[18] Narang AT. (2007). Kerangka Acuan: Pencegahan, Pengendalian Dan Penindakan Terhadap Pelaku Pembakaran hutan, Lahan Dan Pekarangan Di Provinsi Kalimantan Tengah. Palangka Raya: Pemerintah Provinsi Kalimantan Tengah.

[17] Perundang-undangan Indonesia (peraturan pemerintah 4/2001) melarang semua pembakaran hutan dan lahan.

[18] Puspitasari, Rina. (2011). Pemetaan Potensi Kebakaran Hutan pada Kawasan Hutan di Kabupaten Banyuwangi. Yogyakarta : Balai Pemantapan Kawasan Hutan Wilayah XI Jawa-Madura.

[19] Purnama ES, JayaINS. (2007) Pemodelan Spasial Kerawanan Kebakaran Hutanan Lahan Menggunakan Teknologi Sistem Informasi Geografis (SIG) dan Penginderaan Jauh di Propinsi Riau. Journal of Tropical Forest Management 8 (1): 85-97.

[19] Prahasta, Eddy, (2002), Konsep-konsep Dasar Informasi Geografis, Informatika, Bandung

[20] Ruecker, G, 2002. Consultingand Software Developmentto Producea Dinamic Fire Danger Mapfor East Kalimantan. IFFM Documnet Report (Temporary).

[21] Samsuri (2008) Model Spasial Tingkat Kerawanan Kebakaran Hutan dan Lahan (Studi Kasus di Wilayah Propinsi Kalimantan Tengah). [tesis]. Bogor: Institut Pertanian Bogor.

[22] Sekretariat Negara (2001) Peraturan Pemerintah Republik Indonesia Nomor 04 Tahun 2001 Tentang Pengendalian Kerusakan dan atau Pencemaran Lingkungan Hidup yang Berkaitan dengan Kebakaran Hutan dan atau Lahan. Jakarta: Setneg.

[23] Sekretariat Negara (2010) Peraturan Menteri Negara Lingkungan Hidup Nomor 10 Tahun 2010 Tentang Mekanisme Pencegahan Pencemaran Dan/Atau Kerusakan Lingkungan Hidup Yang Berkaitan Dengan Kebakaran Hutan Dan/Atau Lahan. Jakarta: Setneg.

[24] Solichin (2007). Ringkasan Laporan Pencapaian Hasil Kegiatan Sistem Informasi Kebakaran. Palembang: South Sumatra Forest Fire Management Project.

[25] Setijono, Dj. (2001). Kebijakan Pengendalian Kebakaran Hutan dan Lahan di Indonesia: PP No. 4/2001. CV. Dwi Sri Jaya. Bogor.

[26] Suyanto, S. dan Applegate, A. (2001). Akar Penyebab dan Dampak Kebakaran Hutan dan Lahan di Sumatera. CV. Dewi Sri Jaya, Bogor.

[27] Undang-undang Republik Indonesia Nomor 5 Tahun 1990 Tentang Konservasi Sumber Daya Alam Hayati dan Ekosistemnya (Lembaran Negara Republik Indonesia Tahun 1990 No. 49, Tambahan Lembaran Negara No. 3419;

[28] Undang-undang Republik IndonesiaNomor 23 Tahun 1997 tentang Pengelolaan Lingkungan Hidup;

[29] Undang-undang Republik Indonesia Nomor: 32 Tahun 2004 tentang Pemerintahan Daerah; 